\title{
(2) Trade Interference or Good Environmental aße Stewardship: The Case of Gibson Guitar and the Research House Lacey Act
}

\section{Charles Rarick}

Professor of International Business, College of Business, Purdue University Calumet, 2200 169th St. Hammond, IN 46323, USA

E-mail for correspondence: crarick@ purduecal.edu

Cell Phone: +219-989-8161

Received: Jun 05, 2015;

Accepted: Jun 15, 2015;

Published: Jul 07, 2015

Source of Support: Nil

No Conflict of Interest: Declared

\begin{abstract}
The Gibson Guitar Corporation based in Tennessee was raided by federal agents twice for importing prohibited wood products. The raids, especially the second, attracted much public attention and have even led for calls from some members of Congress for a change. The case examines the Lacey Act, the allegations of wrong doing, and the question trade and domestic job creation at the expense of environmental stewardship.
\end{abstract}

Keywords: trade barriers, government regulation, environment, Lacey Act

JEL Classifications Code: F18

"Can you imagine a federal agent saying, 'You're going to jail for five years' and what you do is sort wood in the factory?"

Henry Juszkiewicz, CEO of Gibson Guitar (Hagerty and Maher, 2011)

\section{INTRODUCTION}

In August, 2011 armed federal agents raided two factories of the Gibson Guitar Corporation for alleged violations of the Lacey Act. The agents told Gibson employees to immediately stop working, and it is alleged by $\mathrm{Mr}$. Juszkiewicz that one employee, Gene Nix was told that he could face five years in jail for what he was doing sorting wood. The agents then seized wood, guitars, guitar parts, hard drives, and other records from the plants. This wasn't the first time Gibson had been visited by federal agents, but this time the company decided to use the media to fight back in what it considered to be excessive governmental involvement in private business. The Company alleges that it did nothing wrong and that the federal government cares more about enforcing foreign laws than protecting American jobs. The case involves alleged violations of America's oldest wildlife protection statute, the Lacey Act.

\section{THE LACEY ACT}

Passed in 1900, the Lacey Act named after John Lacey, a Congressman from Iowa, was originally intended to protect and preserve song birds in the United States. The Act was also established to prevent the "unwise" introduction of foreign birds and animals into the country. The Act also was designed to prevent poaching of wildlife in the United States, where game was killed in one state with weaker regulation and shipped to another state. The Act sought greater power for the federal government in matters of wildlife preservation.

Since 1900, the law has been amended, including one amendment in 2008 that extended protection to plants and plant products, including trees. The Amendment makes it illegal to "import, export, sell, receive, acquire, or purchase in interstate or foreign commerce any plant, with limited exceptions, taken or traded in violation of the laws of the U.S., a U.S. State, or relevant foreign law." The Act is enforced by a number of federal agencies. The lead agency is the Animal and Plant Health Inspection Service of the United States Department of Agriculture. Also involved in enforcement is the Department of the Interior's Fish and Wildlife Service, the U.S. Trade Representative, Customs and Border Protection, as well as others agencies. Under the Act, importers are required to submit to U.S. Customs and Border Protection a declaration of the species scientific name, the quantity of the import, country of origin, and monetary value. Violations of the Act carry a fine of up to $\$ 250,000$ and five years in prison.

Relative to the Gibson Guitar case, the provision that is of most concern is the one concerning the violations of foreign laws and the penalties that go with violating the Act. Some have challenged the ability of American businesses to know foreign laws, and the reasonableness of requiring them to help in maintaining those laws. 
Critics such Congressmen Rand Paul and Paul Brown also challenge the "over-criminalization" of the Act, meaning that businesses may have a hard time complying with the Act, yet face severe penalties for violations. Senator Rand Paul and Congressman Paul Broun have proposed legislation called the Freedom from OverCriminalization and Unjust Seizures Act in response to the raid on the Gibson Guitar Company.

The Act does have a diverse level of support among conservationists, labor unions, and the timber industry. The Act helps protect illegal and unfair logging and to preserve endangered plant species. It also can help protect American jobs in the timber industry by closing the U.S. market to illegal logging operations that can cut prices of timber due to rule violations in other counties such as harvesting in national parks. Passage of the Act, as amended, had bipartisan support and was seen as a way to help developing nations protect their natural resources and environments. After the raids at Gibson, the Act has gained increased visibility and has been seen by some as an example of the over-reaching nature of the federal government. Supporters of Gibson in this case include some members of Congress, especially Republican members, Tea Party members, conservation talk radio commentators, and even some environmental groups who feel that a good company has been abused by bad implementation of the law. Gibson's Chief Executive called the raids "bullying" and felt that an old and successful American company was unfairly targeted.

\section{GiBSON GUITARS, History, AND ENVIRONMENT}

The Gibson Guitar Company was founded in the late 1890s by Orville Gibson in Kalamazoo, Michigan. Originally the company produced mandolins that were unique in shape and sound. The mandolins became very popular and the company pioneered more improvements in the instrument, as well as with guitars. In 1935 Gibson developed its first electric guitar and sold the first model called the ES-150 (ES for Electric Spanish) in 1936. During World War II guitar production ceased and the company began making wood products for the war effort. After the War guitar production resumed and the company formed an association with legendary guitar designer, inventor, and singer, Les Paul.

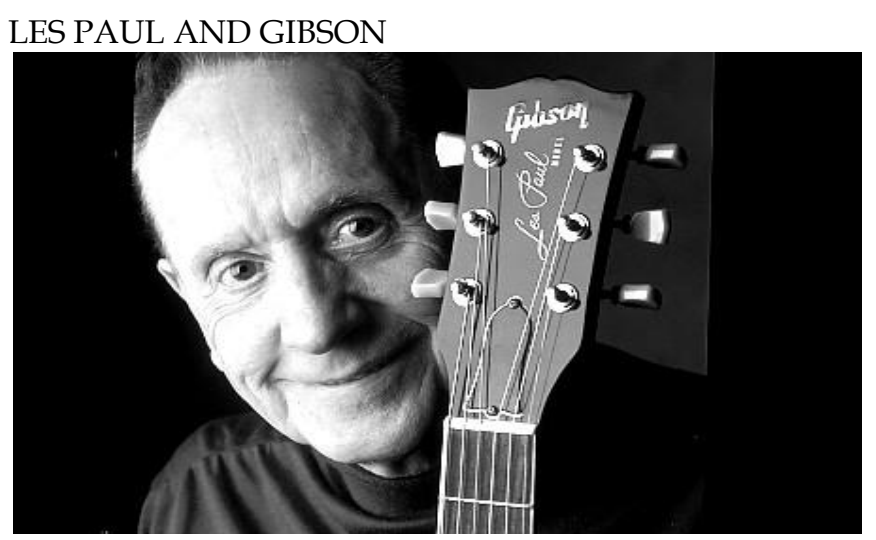

Source: NY Daily News, August 14, 2009
The association with Paul was very beneficial for Gibson. Gibson made and sold many solid body electric guitars and became the standard for the industry. Gibson guitars were used by many famous musicians including Elvis Presley, B.B. King, Chuck Berry, Bob Dylan, Bob Marley, Eric Clapton, Peter Frampton, Sheryl Crow, and many others. Gibson fell on hard time during the 1980s and moved its operations to Nashville in 1984. The company was rescued by its current CEO, Henry Juszkiewicz, and Dave Barryman. Gibson is proud of its "Made in USA" label and employs thousands of workers in its plants in the United States. While the company does produce low-end guitars abroad, all Gibson labeled guitars are made in the United States and carry the tradition of quality manufactured instruments. On a 2009 visit to France by First Lady Michelle Obama, she presented the Gibson Hummingbird guitar as a gift to Carla Bruni, wife of then French president Nicolas Sarkozy. Bruni, a songwriter, and singer, reacted very positively to the gift from Mrs. Obama. Perhaps neither knew that the Hummingbird contained a piece made out of Indian rosewood, the same wood that would trigger the later raid on Gibson by federal agents.

According to attorney Ronald Bienstock, traveling outside the United States presents a danger to Americans if they take guitars or other wood products with them. They may be subject to questioning upon reentry into the United States concerning the source of the wood and face sanctions for possessing illegal wood products. While the First Lady and Mrs. Bruni are probably safe from such scrutiny, others could technically be in possession of contraband and subject to penalties. There has even been talk in the media about possible federal raids on music concerts where Gibson guitars are being used.

Ironically, Gibson Guitar and its CEO, Mr. Juszkiewicz, have been supporters of environmental organizations and efforts designed to save native forests worldwide. According to Greenpeace spokesman, Scott Paul, Gibson has done"great work" in promoting responsible forestry practices. Until the 2011 raid on his company, Juszkiewicz served on the board of the Rainforest Alliance, a group devoted to rainforest preservation. It has been reported that Mr. Juszkiewicz resigned that post in order not to harm the image of the organization.

\section{The RAIDS AND AlLEGations}

Prior to the latest attack on Gibson, in 2009 the company had also been raided by the Fish and Wildlife Service on an allegation that it had illegally imported protected wood from Madagascar. The government of Madagascar prohibits the exporting of unfinished wood from the country. During this raid the government also seized wood, guitars, guitar parts, and company records. Gibson has challenged the raid was illegal since the wood in question was cut into small pieces in Madagascar (finished) and is suing in court for a return of the confiscated goods. Gibson has since stopped buying any wood from Madagascar. 
In the affidavit by the government seeking to acquire search warrants for the latest raid on the Company, John M. Rayfield, Special Agent of the U.S. Fish and Wildlife Service (FWS) stated in part:

I am making this affidavit in support of an application for 4 search warrants authorizing Special Agents of the FWS and the Department of HomelandSecurity (DHS) to search the premises' identified as (1) GIBSON ELECTRICDIVISION Manufacturing Facility, 641 Massman Drive, Nashville, Tennessee 37210; (2) EPIPONE (GIBSON GUITAR CORPORATION) Company Administrative Office and U.S. Distribution Facility, 645 Massman Drive,Nashville, Tennessee 37210; (3) GIBSON GUITAR CORPORATION Company Headquarters, 309 Plus Park, Nashville, Tennessee 37217; andRed Arrow Delivery Service, 1120 Visco Drive, Nashville, TN 37210, and to seize evidence ... of violations of the following laws: Title 16, UnitedStates Code Sections 3372(a)(2)(B) (Lacey Act) and Title 18, United StatesCode, Section 545 (Smuggling.), (Johnson, 2011).

The latest raid of Gibson was carried out on August 24, 2011. According to Gibson, it took days to know what the company had been accused of and to see the affidavit above. The affidavit and raidwere in connection to a June 27, 2011 shipment of wood from India. It is alleged that Gibson falsified the required documentation in order to bypass an Indian government ban on exporting certain raw wood. Gibson admits that there was a discrepancy in the import documents which listed an incorrect tariff code, which they claim was a clerical error made on the part of the importer, Luthiers Mercantile International. Luthier claims the error was made by a low-level and inexperienced employee. The dispute is essentially over whether the Indian rosewood and ebony imported by Gibson is lumber, which would be illegal under Indian law, or if it is not raw wood which is allowed. The Indian government requires the wood in question to be "finished" before exporting.

The wood in question was cut wood stock used for the neck of guitars. The fretboard (Figure 1) is a critical part of the guitar, not only for its functionality but its appearance as well. The fretboard is embedded with frets (metal slats) which are needed to produce notes for proper sound. The frets are embedded at the Gibson factories once the wood arrives and is prepared.

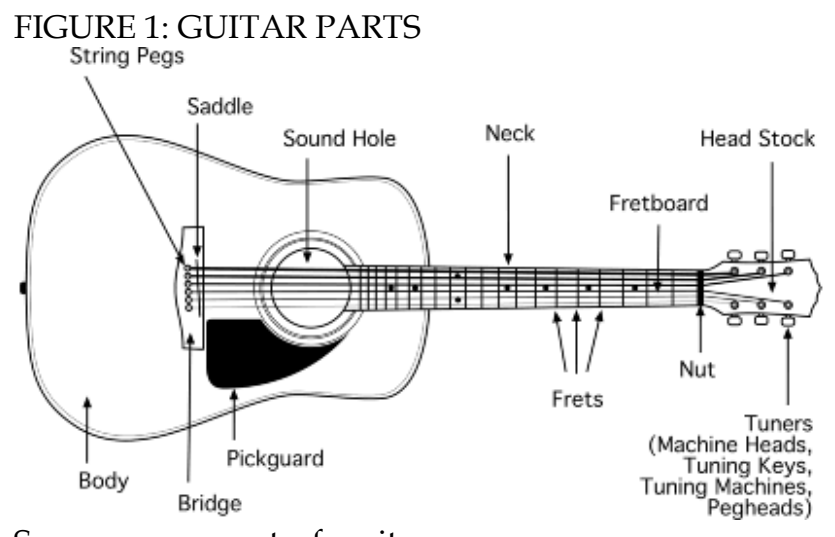

Source: www.partsofaguitar.org
If the frets had been placed in the wood by Indian workers before exporting the Act would not have been considered violated. Gibson contends that the export was approved by the Indian government and was a legal purchase. The question of whether the wood was "unfinished" and illegal under Indian law is based on the interpretation of U.S. government officials. Some observers have questioned the need to conduct such a strong-armed raid by federal agents, given that the security of the United States was not being threatened and that no humans were being put in harm's way. The action is harmful to American employment. The law is also criticized as ambiguous, hard to follow, and subject to interpretation.

\section{Destroying Jobs to Protect Foreign Laws}

The protection and preservation of the world's natural resources is an important concern for all. Given that the earth's ecosystem is interconnected, it behooves us all to be concerned about environmental damage, wherever it occurs. Air pollution produced in China ends up spilling over into California. Manmade greenhouse gases are alleged to be causing global warming. Industrial runoff which makes its way into the oceans results in some species of fish containing harmful levels of mercury. Deforestation in Indonesia, Brazil, Malaysia, Russia and other countries has caused global concern.

Madagascar, the source of some of the wood in question in the case, has been especially hard hit by massive deforestation and soil erosion, and the over-hunting of animals. The country has experienced severe environmental damage and exploitation of its natural resources. The impoverished country has also experienced political unrest starting in 2009, which resulted in the loss of international business and foreign investment. In part, the political unrest is due to the environmental damage of the country and the mismanagement of its natural resources.

In 2012, Gibson settled with the government and admitted to violating the Lacey Act. The Company was fined $\$ 300,000$ and forfeited the wood in question. Still maintaining the Company's innocence, CEO Juszkiewicz stated that it was cheaper to settle the case and pay the fine than to fight in court.

While most would agree that protecting the environment is a worthy cause, some worry that in doing so a resulting loss of jobs may result. Countries with weak or poorly enforced environmental laws can produce products more cheaply than countries with strong environmental protection. According to Gibson, the federal raids of the company cost the firm millions of dollars and are an example of excessive regulation that encourage American companies to manufacturer abroad. Supporters of the government's action feel that it is necessary to send a message to American companies not to facilitate the violation of other countries laws, and to protect developing countries that lack the ability to enforce their own environmental regulations. While the Gibson case 
gained widespread publicity, the government has continued to prosecute companies and individuals under the Act. In April of 2015 it was announced that Lumber Liquidators, a large American wooden flooring company was being charged with criminal violations under the Lacey Act. The government it appears is moving forward with strict enforcement of the Lacey Act.

\section{Discussion QUESTIONS}

1. Given the size of its economy, does the United States have any special duty or role in preventing problems caused by environmental mismanagement?

2. Does the Lacey Act unfairly interfere with global trade in your opinion? Explain your answer.

3. How do you propose balancing the requirements of environmental stewardship and trade promotion?

\section{REFERENCES}

Anderson, R. (1995). The Lacey Act: America's premier weapon in the fight against unlawful wildlife trafficking. Public Land Law Review, vol. 16.

Barnerjee, N. (2011). Gibson Guitar raid strikes a chord with conservatives. The Seattle Times, September 29.
Combs, H. (2011).Gibson raid raises attention on Lacey Act enforcement. Furniture Today, September 6.

Hagerty, J. and K. Maher. (2011). Gibson Guitar wails on federal raid over wood. The Wall Street Journal, September 1.

Havighurst, G. (2011). Why Gibson Guitar was raided by the Justice Department. NPR, August 31.

Johnson, A. (2011). Details from the Gibson Guitar search warrant.Nashville Business Journal, August 26.

Meek, A. (2011).How Gibson went Tea Party. The Daily Beast, September 9.

Miller, S. and Y de Nies.(2009). Gifter-In-Chief? Michelle Obama gives Carla Bruni a guitar. ABCNews.com. April 5.

Mohan, G. (2012). Wood protection law creates splintering in guitar industry. Bangor Daily News, January 25.

Prentice-Dunn, J. (2015).Lumber Liquidators may face criminal charges over illegal wood products.Sierra Club. April 29.

Roberts, J. (2011). Is fed raid on Gibson Guitar Company enforcing policy ... or a push to target "Made in the USA"?FoxNews.com. September 7.

Schmidt, J. (2011). Lacey Act: The diverse coalition that supports it and why efforts to weaken it should be resisted. News Wire, October 5.

www.cbp.gov. Accessed on October 10, 2011.

www.gibson.com. Accessed on September 5, 2011 and June 3, 2015.

$--0-$ 